\title{
ANALISIS PENGARUH HUTANG JANGKA PANJANG, HUTANG JANGKA PENDEK DAN MODAL KERJA BERSIH TERHADAP LABA PADA PT. GRIYA ASRI PRIMA
}

\author{
Oleh: Desilia Purnama Dewi \\ (Desiliadewi3@gmail.com)
}

\begin{abstract}
ABSTRAK
Keuangan suatu perusahaan merupakan suatu bidang dalam keuangan yang mendapat perhatian dan mempunyai pengaruh yang cukup besar terhadap nilai perusahaan. Sering kali para pengambil keputusan memperhatikan struktur keuangan perusahaan dalam rangka investasi ke perusahaan yang bersangkutan. Perbankan juga memperhatikan struktur keuangan untuk memberikan kredit ke suatu perusahaan. Baik kreditur jangka pendek maupun kreditur jangka panjang dan pemegang saham, keduaduanya akan memperhatikan kondisi keuangan jangka pendek dan kondisi keuangan jangka panjang, hanya tekanan perhatiannya yang berbeda.
\end{abstract}

\section{Kata Kunci : Hutang, Modal kerja, Laba.}

\section{PENDAHULUAN}

\section{A. Latar Belakang}

Perusahaan yang sedang berkembang memerlukan modal untuk menjalankan keputusan dalam melakukan investasi. Modal tersebut dapat diperoleh dari keuntungan maupun ekuitas, hal tersebut menimbulkan suatu keputusan penting yang harus diambil oleh seorang manajer keuangan yaitu keputusan dalam memperoleh modal dalam memenuhi kebutuhan investasi, karena setiap sumber pendanaan yang berbeda akan mempunyai implikasi yang berbeda pula pada perusahaan.

Dari pendanaan yang diperoleh tersebut akan digunakan perusahaan untuk membiayai investasi sehingga perusahaan dapat memperoleh keuntungan atas pendanaan asset yang dilakukan. Modal senantiasa menjadi persoalan mendasar bagi dunia bisnis, terutama di dalam menghadapi persaingan di era globalisasi. Tersedianya modal merupakan kebutuhan mutlak yang harus dipenuhi, jika tidak tersedia modal, sulit untuk 
mengembangkan kinerja usaha dan bersaing dalam pentas dunia. Pada prinsipnya pemenuhan kebutuhan dana suatu perusahaan dapat disediakan dari sumber intern perusahaan yaitu sumber dana yang dibentuk atau dihasilkan sendiri dalam perusahaan.

Untuk melaksanakan fungsi pemenuhan kebutuhan dana, manajer keuangan harus selalu mencari alternatif-alternatif sumber dana dan diambil keputusan alternatif sumber dana mana yang akan dipilih. Selain dalam melakukan pemanfaatan dana, manajemen juga harus mampu memanfaatkan dengan maksimal seluruh potensi yang ada dalam perusahaan, salah satu faktor yang harus diperhatikan dan dimaksimumkan pemanfaatannya adalah modal kerja. Modal kerja didefinisikan sebagai aktiva lancar dikurangi dengan kewajiban lancar. Jadi, modal kerja merupakan investasi perusahaan dalam bentuk uang tunai, surat berharga, piutang dan persediaan, dikurangi dengan kewajiban lancar yang digunakan untuk membiayai aktiva lancar.

Modal kerja sebaiknya tersedia dalam jumlah yang cukup agar memungkinkan perusahaan untuk beroperasi secara ekonomis dan tidak mengalami kesulitan keuangan, keputusan yang berkaitan dengan modal kerja juga harus diambil dengan hati-hati, karena jika perusahaan tidak dapat mempertahankan tingkat modal kerja dengan baik maka kemungkinan perusahaan akan berada dalam keadaan insolvent (tidak mampu membayar kewajiban-kewajiban yang sudah jatuh tempo) dan bahkan mungkin bisa bangkrut. Namun, jumlah modal kerja juga harus dijaga agar tidak berlebihan sehingga terdapat dana yang menganggur yang tidak produktif (idlefund).

Ukuran yang sering kali digunakan untuk menentukan sukses tidaknya manajemen perusahaan adalah laba yang diperoleh perusahaan. Pengukuran laba bukan saja penting untuk menentukan prestasi perusahaan, tetapi penting juga sebagai informasi bagi pembagian laba dan penentuan kebijakan investasi. Laba atau rugi sering dimanfaatkan sebagai ukuran untuk menilai prestasi perusahaan atau sebagai dasar penilaian yang lain, seperti laba per lembar saham. Unsur-unsur yang menjadi bagian pembentuk laba adalah pendapatan dan biaya. Dengan mengelompokkan unsur-unsur pendapatan dan biaya, akan dapat diperoleh hasil pengukuran laba yang berbeda antara lain laba kotor, laba operasi, laba sebelum pajak, dan laba bersih. Suatu perusahaan dapat tumbuh dan berkembang, hal ini tentunya tidak lepas dari pengelolaan hutang dan modal kerja yang dimiliki.

Dari uraian di atas, maka penulis sangat tertarik untuk meneliti "Analisis Pengaruh Hutang Jangka Panjang, Hutang Jangka Pendek dan Modal Kerja Bersih Terhadap Laba Pada PT Griya Asri Prima" sebagai judul dari penelitian penulis ini. 


\section{B. Permasalahan}

Dari permasalahan yang telah penulis kemukakan, maka penulis akan merumuskan beberapa permasalahan, yaitu:

1. Seberapa besar pengaruh hutang jangka panjang terhadap laba.

2. Seberapa besar pengaruh hutang jangka pendek terhadap laba.

3. Seberapa besar pengaruh modal kerja bersih terhadap laba.

4. Seberapa besar pengaruh hutang jangka panjang, hutang jangka pendek dan modal kerja bersih secara bersama-sama terhadap laba.

\section{Tempat dan Waktu Penelitian}

\section{Tempat Penelitian}

Tempat yang menjadi objek penelitian adalah PT Griya Asri Prima yang berlokasi di Jl. Gudang Peluru Barat IV No. 8 (Blok V-531) Tebet-Jakarta Selatan 12830. Telp. (021) 829 7366, 831 6272, 831 8460, email : info@griya-asri.com. Website : www.griya-asri.com.

\section{Waktu Penelitian}

Penelitian ini dilakukan dari bulan Juli sampai Desember 2012, waktu penelitain ini telah dilakukan secara bertahap antara lain diawali pengumpulan data, persetujuan pembimbing, konsultasi permasalahan, penulisan proposal penelitian, seminar proposal penelitian, pengolahan dan analisa data, perbaikan laporan serta sidang akhir penelitian.

\section{Penyusunan Kerangka Teoritik, Kerangka Berpikir dan Pengajuan Hipopenelitian}

1. Deskripsi Teoritik

\subsection{Manajemen Keuangan}

a. Pengertian Manajemen Keuangan

b. Tujuan, Tugas dan Fungsi Manajemen Keuangan

1.2 Laporan Keuangan
a. Pengertian laporan Keuangan
b. Jenis/produk laporan Keuangan
c. Keterbatasan Lporan Keuangan 


\section{E. Pembahasan}

\section{a. Hutang Jangka Panjang}

\section{Pengertian Hutang Jangka Panjang}

Menurut Umi muamanah (2008:577) hutang jangka panjang adalah kewajiban yang pelunasannya atau jatuh temponya lebih dari satu tahun atau satu periode akuntansi.

Jumingan (2005:26) mendefinisikan hutang jangka panjang sebagai kewajiban perusahaan kepada pihak lain yang harus dipenuhi dalam jangka waktu melebihi satu tahun. Timbulnya pinjaman ini umumnya karena perusahaan memerlukan dana besar untuk membelanjai perluasan pabrik, tambahan perlengkapan, modal kerja, atau tanah, melunasi hutang jangka pendek atau hutang jangka panjang lainnya.

Hutang jangka panjang menurut Kieso (2002 : 242) terdiri dari pengorbanan manfaat ekonomi yang sangat mungkin di masa depan akibat kewajiban sekarang yang tidak dibayarkan dalam satu tahun atau siklus operasi perusahaaan mana yang lebih lama.

Berdasarkan pengertian di atas dapat disimpulkan bahwa hutang jangka panjang adalah kewajiban perusahaan kepada pihak lain yang harus dipenuhi dalam jangka waktu melebihi satu tahun.

\section{b. Hutang Jangka Pendek}

Menurut Jumingan (2005:25) hutang jangka pendek adalah kewajiban perusahaan kepada pihak lain yang harus dipenuhi dalam jangka waktu normal, umumnya satu tahun atau kurang, semenjak neraca disusun, atau hutang yang jatuh temponya masuk siklus akuntansi yang sedang berjalan.

Umi muamanah (2008:562) mendefinisikan hutang jangka pendek adalah kewajiban yang harus dibayar atau diselesaikan dalam waktu satu periode siklus akuntansi atau dalam waktu satu tahun dengan menggunakan kas, barang atau jasa.

Yusuf (2005 : 230) mendefinisikannya hutang jangka pendek adalah hutang yang diharapkan akan dibayar dalam jangka waktu satu tahun atau siklus akuntansi operasi normal perusahaan dengan menggunakan aktiva lancar atau hasil pembentukan kewajiban lancar yang lain.

Berdasarkan pengertian-pengertian di atas dapat disimpulkan bahwa hutang jangka pendek adalah kewajiban yang akan jatuh tempo dalam waktu satu tahun. 


\section{c. Modal Kerja}

Jumingan (2005:66) mengutip dari buku yang ditulis Bambang Riyanto, mengatakan terdapat beberapa definisi modal kerja, antara lain:

1) Modal kerja bersih (net working capital) adalah kelebihan aktiva lancar terhadap hutang jangka pendek, kelebihan ini merupakan jumlah aktiva lancar yang berasal dari hutang jangka panjang dan modal sendiri.

2) Modal kerja bruto (gross working capital) adalah jumlah dari aktiva lancar.

Modal kerja menurut definisi di atas hanyalah jumlah dana yang digunakan selama periode akuntansi yang dimaksudkan untuk menghasilkan pendapatan jangka pendek saja, yaitu berupa kas, persediaan barang dagang, piutang dan penyusutan aktiva tetap. Adapun aktiva lancar seperti surat-surat berharga dan keuntungan dalam piutang digolongkan sebagai modal kerja potensial. Aktiva tidak lancar seperti tanah,bangunan, mesin dan lain-lain digolongkan sebagai net working capital.

\section{Laba}

Pengukuran laba bukan saja penting untuk menentukan prestasi perusahaan, tetapi penting juga sebagai informasi bagi pembagian laba dan penentuan kebijakan investasi. Laba atau rugi sering dimanfaatkan sebagai ukuran untuk menilai prestasi perusahaan atau sebagai dasar penilaian yang lain, seperti laba per lembar saham. Unsur-unsur yang menjadi bagian pembentuk laba adalah pendapatan dan biaya. Dengan mengelompokkan unsur-unsur pendapatan dan biaya, akan dapat diperoleh hasil pengukuran laba yang berbeda antara lain laba kotor, laba operasi, laba sebelum pajak, dan laba bersih.

Pengertian laba menurut Harnanto adalah selisih dari pendapatan atas biaya-biaya dalam jangka waktu (periode) tertentu. Laba sering digunakan sebagai suatu dasar untuk pengenaan pajak, kebijakan dividen, pedoman investasi serta pengambilan keputusan dan unsur prediksi.

Laba merupakan selisih antara pendapatan dan biaya secara akrual. Berdasarkan konsep ini, James O. Gill dan Moira Chatton (2006:18) mendefinisikan laba operasi sebagai pendapatan yang diperoleh dari laba kotor dikurangi biaya operasi. 


\section{Populasi dan Sample}

Populasi yang digunakan dalam penelitian ini adalah Laporan Keuangan PT. GRIYA ASRI PRIMA selama 36 (tiga puluh enam) bulan atau dari tahun 2008 sampai dengan tahun 2010. Sedangkan sampel yang digunakan dalam penelitian ini yaitu berupa Neraca dan Laporan Laba/Rugi PT. GRIYA ASRI PRIMA selama 36 (tiga puluh enam) bulan atau dari tahun 2008 sampai dengan tahun 2010.

\section{Teknik Pengumpulan Data}

Metode yang digunakan dalam pengumpulan data untuk melakukan penelitian ini adalah dengan menggunakan metode field research. Penelitian lapangan ini dilakukan dengan mengumpulkan data-data dan informasi dengan cara: observasi, yaitu melakukan pengamatan langsung ke lokasi penelitian yaitu pada PT. GRIYA ASRI PRIMA, dengan tujuan mendapatkan data yang relevan mengenai masalah yang akan diteliti. Dokumentasi, metode dokumentasi ini digunakan untuk memperoleh data yang berhubungan dengan sejarah berdirinya perusahaan, struktur organisasi perusahaan, dan laporan keuangan dari tahun 20042010. Kemudian dengan wawancara, metode yang digunakan untuk memperoleh data penunjang untuk membantu proses penelitian, yaitu untuk mencocokan antara data yang telah ada dengan keadaan sebenarnya.

\section{Metode Analisa Data}

Teknik analisa data yang penulis gunakan dalam penelitian ini adalah regresi linier berganda dengan menggunakan Software Statistic Program for Social Science (SPSS) Versi 16.00 .

\section{Uji Asumsi Klasik}

\section{Uji Multikolinieritas}

Uji multikolinieritas bertujuan untuk menguji apakah pada model regresi ditemukan adanya korelasi antar variabel independent (Gozali, 2006) jika terjadi korelasi maka dinamakan terdapat problem multikolineritas. Model regresi yang baik sebaiknya tidak terjadi korelasi diantara variabel independent. Untuk mengolah uji multikolinieritas maka digunakan software SPSS (Statistical Program for Social Science)versi 16.00 for windows. 


\section{Uji Heteroskedasitas}

Uji ini bertujuan untuk menguji apakah dalam model regresi terjadi ketidaksamaan varians dari residual suatu pengamatan ke pengamatan yang lain (Ghozali, 2006). Jika varians dari residual suatu pengamatan ke pengamatan yang lain tetap, maka di sebut homokedasitas dan jika berbeda di sebut heteroskedasitas. Model regresi yang baik adalah yang homokedasitas atau tidak terjadi heteroskedasitas (Ghozali, 2006).

\section{Uji Autokorelasi}

Uji autokorelasi bertujuan untuk menguji apakah model regresi linier ada korelasi antara kesalahan pengganggu pada periode $t$ dengan kesalahan pengganggu pada periode $t$ 1 (sebelumnya). Jika terjadi korelasi maka ada masalah autokorelasi. Autokorelasi muncul karena masalah observasi yang berurutan sepanjang waktu berkaitan satu dengan yang lain. Masalah ini timbul karena residual (kesalahan pengganggu) tidak bebas dari satu observasi ke observasi lainnya, biasanya dijumpai pada data deret waktu (time series). Konsekuensi adanya autokorelasi dalam model regresi adalah variance sample tidak dapat menggambarkan variance populasinya. Sehingga model regresi yang dihasilkan tidak dapat digunakan untuk menaksir nilai variabel dependen pada nilai independen tertentu (Ghozali, 2005).

\section{Uji Normalitas}

Uji normalitas bertujuan untuk menguji apakah dalam model regresi, variabel dependen dan variabel independen mempunyai distribusi normal atau tidak. Model regresi yang baik memiliki distribusi data normal atau mendekati normal.

\section{Regresi Linier Berganda}

Menurut Sugiono (2009 : 277) analisis regresi ganda umumnya digunakan oleh peneliti, bila peneliti bermaksud untuk meramalkan bagaimana keadaan (naik turunnya) variabel dependen, bila dua atau lebih variabel independen sebagai faktor prediktor dimanipulasi (dinaik turunkan nilainya). Jadi analisis ganda akan dilakukan bila jumlah variabel independennya minimal dua. bentuk persamaan garis regresinya adalah:

$$
Y=a+b_{1} X_{1}+b_{2} X_{2}+b_{3} X_{3}
$$


Dimana:

$\mathrm{Y} \quad=$ Variabel terikat $(\mathrm{laba})$

$\mathrm{X}_{1} \mathrm{X}_{2} \mathrm{X}_{3}=$ Variabel bebas I, II dan III (hutang jangka panjang, hutang jangka pendek, dan modal kerja bersih)

a $\quad$ intercept atau konstanta

$\mathrm{b}_{1}, \mathrm{~b}_{2}$ dan $\mathrm{b}_{3}=$ Koefisien regresi (gradien)

\section{Koefisien Determinasi $\left(\mathbf{R}^{2}\right)$}

Koefisien determinasi $\left(\mathrm{R}^{2}\right)$ pada umumnya mengukur seberapa jauh kemampuan model dalam menerangkan variabel dependen. Nilai $\mathrm{R}^{2}$ yang kecil berarti kemampuan variabel-variabel independen dalam menjelaskan variabel dependen terbatas, sebaliknya nilai $\mathrm{R}^{2}$ yang mendekati satu menandakan variabel-variabel independen memberikan hampir semua informasi yang dibutuhkan oleh variabel dependen (Ghozali: 2005). Nilai yang digunakan adalah adjusted $\mathrm{R}^{2}$ karena variabel independen yang digunakan dalam penelitian ini lebih dari dua buah.

\section{Pengujian Hipotesis (Uji statistik)}

Setelah melakukan pengujian normalitas dan pengujian atas asumsi-asumsi klasik, langkah selanjutnya yaitu melakukan pengujian atas hipotesis $1\left(\mathrm{H}_{1}\right)$ hipotesis $2\left(\mathrm{H}_{2}\right)$ sampai dengan hipotesis $3\left(\mathrm{H}_{3}\right)$. Pengujian tingkat penting (test of significance) ini merupakan suatu prosedur di mana hasil sampel digunakan untuk menguji kebenaran suatu hipotesis (Gujarati, 1999) dengan alat analisis yaitu uji t dan uji F. Perhitungan statistik disebut signifikan secara statistik apabila uji nilai statistiknya berada dalam daerah kritis (daerah dimana $\mathrm{H}_{0}$ ditolak). Sebaliknya, disebut tidak signifikan bila uji nilai statistiknya berada dalam daerah di mana $\mathrm{H}_{0}$ diterima.

\section{HASIL PENELITIAN DAN PEMBAHASAN}

Dari hasil perhitungan dengan menggunakan software Statstical Program for Social Secience (SPSS) versi 16.00, maka dapat dipaparkan analisis pengaruh hutang jangka panjang, hutang 
jangka pendek, dan modal kerja bersih secara bersama-sama terhadap laba pada PT. Griya Asri Prima sebagai berikut:

\section{Pengaruh Hutang Jangka Panjang Terhadap Laba Pada PT. Griya Asri Prima}

Berikut hasil yang penulis telah olah dengan menggunakan program IBM Spss (Statistical Program for Social Science) versi 16.00 for windows, variabel $\mathrm{X}_{1}$ terhadap variabel Y sebagai berikut:

Tabel 4-1. Koefisien Determinasi Hutang Jangka Panjang Terhadap Laba

\section{Model Summary}

\begin{tabular}{|l|l|l|l|l|l|}
\hline \multirow{2}{*}{ Model } & $\mathrm{R}$ & R Square & $\begin{array}{l}\text { Adjusted } \\
\text { Square }\end{array}$ & $\begin{array}{l}\text { Std. Error of } \\
\text { the Estimate }\end{array}$ & $\begin{array}{l}\text { Durbin- } \\
\text { Watson }\end{array}$ \\
\hline 1 &, $627^{\mathrm{a}}$ &, 393 &, 376 & 284,4846634 &, 153 \\
\hline
\end{tabular}

a. Predictors: (Constant), Hutang_Jangka_Panjang

b. Dependent Variable: Laba

Sumber: Data Diolah Dengan SPSS Versi 16.00

Tabel 4-2. Model Regresi Hutang Jangka PanjangTerhadap Laba

Coefficients $^{\mathrm{a}}$

\begin{tabular}{|cl|l|l|l|l|l|}
\hline \multirow{2}{*}{ Model } & \multicolumn{2}{|l|}{$\begin{array}{l}\text { Unstandardized } \\
\text { Coefficients }\end{array}$} & $\begin{array}{l}\text { Standardized } \\
\text { Coefficients }\end{array}$ & & \\
\cline { 2 - 5 } & B & Std. Error & Beta & t & Sig. \\
\hline 1 & $\begin{array}{l}\text { (Constant) } \\
\text { Hutang_Jangka_Panjang }\end{array}$ & $-3,635$ &, 774 &,- 627 & $-4,696$ &, 000 \\
\hline
\end{tabular}

a. Dependent Variable: Laba

Sumber: Data Diolah Dengan SPSS versi 16.00

Dari output data table-tabel 4-1 dan 4-2 dapat diperoleh hasil sebagai berikut:

- Korelasi antara hutang jangka panjang terhadap laba adalah 0,627. Dapat dikatakan bahwa ada hubungan positif dan sedang sebesar 0,627 antara variabel hutang jangka panjang terhadap laba pada PT. Griya Asri Prima.

- Model regresi yang diperoleh adalah $\mathrm{Y}=537.699+(-3,635) \mathrm{X}_{1}$

- Model regresi sederhana ini memberikan kesimpulan bahwa:

- Konstanta sebesar 537.699 dapat dikatakan bahwa tanpa variabel hutang jangka panjang, besarnya laba pada PT. Griya Asri Prima tetap terbentuk sebesar 537.699. 
- Variabel hutang jangka panjang $\left(\mathrm{X}_{1}\right)$ berpengaruh negatif terhadap laba (Y) dengan nilai koefisien regresi sebesar -3,635. Yang artinya jika variabel hutang jangka panjang menigkat satu satuan maka laba pada PT. Griya Asri Prima akan menurun sebesar 3,635

- Nilai $\mathrm{R}^{2}$ sebesar 0,393. Data tersebut mengidentifikasikan bahwa hutang jangka panjang memberikan konstribusi sebesar 39,3\% terhadap laba pada PT. Griya Asri Prima. dan selebihnya $60,7 \%$ disebabkan oleh faktor-faktor lain.

- Nilai $t_{\text {hitung }}$ sebesar -4,696 dengan signifikansi $\mathrm{t}$ sebesar 0,000 . Nilai $\mathrm{t}_{\text {tabel }}=\mathrm{t}(0,05 ; 32)$ 1,648, karena nilai $t_{\text {hitung }}$ sebesar $-4,887$ dengan signifikansi t sebesar 0,000 . Hal ini menunjukkan bahwa ada pengaruh negatif variabel hutang jangka panjang terhadap laba pada PT. Griya Asri Prima.

\section{Pengaruh Hutang Jangka Pendek Terhadap Laba Pada PT. Griya Asri Prima}

Berikut hasil yang penulis telah olah dengan menggunakan program IBM Spss (Statistical Program for Social Science) versi 16.00 for windows, variabel $\mathrm{X}_{2}$ terhadap variabel Y sebagai berikut:

Tabel 4-3. Koefisien Determinasi Hutang Jangka Pendek Terhadap Laba Model Summary ${ }^{b}$

\begin{tabular}{|l|l|l|l|l|l|}
\hline Model & $R$ & R Square & $\begin{array}{l}\text { Adjusted R } \\
\text { Square }\end{array}$ & $\begin{array}{l}\text { Std. Error of } \\
\text { the Estimate }\end{array}$ & Durbin-Watson \\
\hline 1 &, $048^{\mathrm{a}}$ &, 002 &,- 027 & 364,8568323 &, 091 \\
\hline
\end{tabular}

a. Predictors: (Constant), Hutang_Jangka_Pendek

b. Dependent Variable: Laba

Sumber: Data Diolah Dengan SPSS versi 16.00

Tabel 4-4. Model Regresi Hutang Jangka Pendek Terhadap Laba

Coefficients $^{\mathrm{a}}$

\begin{tabular}{|c|c|c|c|c|c|}
\hline \multirow[b]{2}{*}{ Model } & \multicolumn{2}{|c|}{$\begin{array}{l}\text { Unstandardized } \\
\text { Coefficients }\end{array}$} & \multirow{2}{*}{$\begin{array}{l}\text { Standardized } \\
\text { Coefficients }\end{array}$} & \multirow[b]{2}{*}{$\mathrm{T}$} & \multirow[b]{2}{*}{ Sig. } \\
\hline & B & Std. Error & & & \\
\hline 1 (Constant) & 246,066 & 364,444 & &, 675 &, 504 \\
\hline Hutang_Jangka_Pendek &, 068 &, 241 &, 048 &, 282 &, 780 \\
\hline
\end{tabular}

a. Dependent Variable: Laba 
Sumber: Data Diolah Dengan SPSS versi 16.00

Dari output data table-tabel 4-3 dan 4-4 dapat diperoleh hasil sebagai berikut:

- Korelasi antara hutang jangka pendek terhadap laba adalah sebesar 0,048, Memberikan arti bahwa antara hutang jangka pendek dengan laba yang dicapai terdapat hubungan yang positif dan sangat rendah, ini berarti jika hutang jangka pendek diperbesar/dikurangi, maka laba akan meningkat/menurun.

- Model regresi yang diperoleh adalah $\mathrm{Y}=246,066+0,068 \mathrm{X}_{2}$

- Model regresi sederhana ini memberikan kesimpulan bahwa:

- Konstanta sebesar 246,066 dapat dikatakan bahwa tanpa variabel hutang jangka pendek, besarnya laba pada PT. Griya Asri Prima tetap terbentuk sebesar 246,066.

- Variabel hutang Jangka Pendek $\left(\mathrm{X}_{2}\right)$ berpengaruh positif terhadap laba (Y) dengan nilai koefisien regresi sebesar 0,068. Yang artinya jika variabel hutang jangka pendek menigkat satu satuan maka laba pada PT. Griya Asri Prima akan meningkat sebesar 0,068 .

- Nilai $\mathrm{R}^{2}$ sebesar 0,002. Data tersebut mengidentifikasikan bahwa hutang jangka pendek memberikan konstribusi sebesar 0,02\% terhadap laba pada PT. Griya Asri Prima dan selebihnya 99,98\% disebabkan oleh faktor-faktor lain.

- Nilai thitung sebesar 0,282 dengan signifikansi t sebesar 0,780, nilai $t_{\text {tabel }}=\mathrm{t}(0,05 ; 32) 1,648$. Karena nilai $\mathrm{t}_{\text {hitung }}<\mathrm{t}_{\text {tabel }}(0,780<1,648)$ dan signifikasi $\mathrm{t}>0,05(0,780>0,05)$, maka $\mathrm{H}_{2} \leq$ 0 ditolak $\mathrm{H}_{2} \geq 0$ diterima. Hal ini menunjukkan bahwa tidak ada pengaruhnya antara variabel hutang jangka pendek terhadap laba pada PT. Griya Asri Prima.

\section{Pengaruh Modal Kerja Bersih Terhadap Laba Pada PT. Griya Asri Prima}

Berikut hasil yang penulis telah olah dengan menggunakan program IBM Spss (Statistical Program for Social Science) versi 16.00 for windows, variabel $\mathrm{X}_{3}$ terhadap variabel Y sebagai berikut:

Tabel 4-5. Koefisien Determinasi Modal Kerja Bersih Terhadap Laba

Model Summary ${ }^{\mathbf{b}}$
\begin{tabular}{|l|l|l|l|l|l|}
\hline Model & R & R Square & $\begin{array}{l}\text { Adjusted R R } \\
\text { Square }\end{array}$ & $\begin{array}{l}\text { Std. Error of } \\
\text { the Estimate }\end{array}$ & Durbin-Watson \\
\hline 1 &, $948^{\mathrm{a}}$ &, 899 &, 896 & 116,2586028 &, 691 \\
\hline
\end{tabular}
a. Predictors: (Constant), Modal_Kerja_Bersih
b. Dependent Variable: Laba
Sumber: Data Diolah Dengan SPSS versi 16.00 
Tabel 4-6. Model Regresi Modal Kerja Bersih Terhadap Laba

Coefficients $^{\mathrm{a}}$

\begin{tabular}{|ll|l|l|l|l|l|}
\hline \multicolumn{2}{|c|}{} & \multicolumn{2}{|l|}{$\begin{array}{l}\text { Unstandardized } \\
\text { Coefficients }\end{array}$} & $\begin{array}{l}\text { Standardized } \\
\text { Coefficients }\end{array}$ & & \\
\cline { 2 - 5 } Model & B & Std. Error & Beta & t & Sig. \\
\hline 1 & $\begin{array}{l}\text { (Constant) } \\
\text { Modal_Kerja_Bersi } \\
\text { h }\end{array}$ & $-2533,033$ & 166,965 & & $-15,171$ &, 000 \\
\hline
\end{tabular}

a. Dependent Variable: Laba

Sumber: Data Diolah Dengan SPSS versi 16.00

Dari output data table-tabel 4-5 dan 4-6 dapat diperoleh hasil sebagai berikut:

- Korelasi antara modal kerja bersih terhadap laba adalah 0,948. Memberikan arti bahwa antara modal kerja bersih dengan laba yang dicapai terdapat hubungan yang positif dan sangat tinggi, ini berarti jika modal kerja bersih diperbesar/dikurangi, maka laba akan meningkat/menurun.

- Model regresi yang diperoleh adalah $\mathrm{Y}=-2.533,033+0,836 \mathrm{X}_{3}$

- Model regresi sederhana ini memberikan kesimpulan bahwa:

- Konstanta sebesar -2.533,033 dapat dikatakan bahwa tanpa variabel modal kerja bersih, besarnya laba pada PT. Griya Asri Prima tetap terbentuk sebesar -2533,033

- Variabel modal kerja bersih $\left(\mathrm{X}_{3}\right)$ berpengaruh positif terhadap laba $(\mathrm{Y})$ dengan nilai koefisien sebesar 0,836 . Yang artinya jika variabel modal kerja bersih menigkat satu satuan maka laba pada PT. Griya Asri Prima akan meningkat sebesar 0,836.

- Nilai $\mathrm{R}^{2}$ sebesar 0,899. Data tersebut mengidentifikasikan bahwa modal kerja bersih memberikan konstribusi sebesar 89,9\% terhadap laba pada PT. Griya Asri Prima, dan selebihnya $10,1 \%$ disebabkan oleh faktor-faktor lain.

- Nilai thitung sebesar 17,368 dengan signifikansi t sebesar 0,000 , dan nilai $t_{\text {tabel }}=\mathrm{t}(0,05 ; 32)$ 1,648. Karena nilai $t_{\text {hitung }}>t_{\text {tabel }}(17,368>1,648)$ dan signifikasi $t<0,05(0,000<0,05)$, 
maka $\mathrm{H}_{3} \leq 0$ ditolak $\mathrm{H}_{3} \geq 0$ diterima. Hal ini menunjukkan bahwa modal kerja bersih berpengaruh positif dan signifikan terhadap laba pada PT. Griya Asri Prima..

\section{Pengaruh Hutang Jangka Panjang, Hutang Jangka Pendek dan Modal Kerja Bersih} Secara Bersama-sama Terhadap Laba Pada PT. Griya Asri Prima

Adapun hasil pengolahan menggunakan program IBM Spss (Statistical Program for Social Science) versi 16.00 for windows, variabel $\mathrm{X}_{1}, \mathrm{X}_{2}, \mathrm{X}_{3}$ terhadap variabel $\mathrm{Y}$ sebagai berikut:

Tabel 4-7. Hasil Uji Regresi Berganda

Coefficients $^{\mathrm{a}}$

\begin{tabular}{|c|c|c|c|c|c|}
\hline \multirow[b]{2}{*}{ Model } & \multicolumn{2}{|c|}{$\begin{array}{l}\text { Unstandardized } \\
\text { Coefficients }\end{array}$} & \multirow{2}{*}{\begin{tabular}{|l} 
Standardized \\
Coefficients
\end{tabular}} & \multirow[b]{2}{*}{$\mathrm{t}$} & \multirow[b]{2}{*}{ Sig. } \\
\hline & B & Std. Error & & & \\
\hline (Constant) & $-2348,133$ & 345,720 & & $-6,792$ &, 000 \\
\hline Hutang_Jangka_Panjang &,- 582 &, 507 &,- 100 & $-1,149$ &, 259 \\
\hline Hutang_Jangka_Pendek &, 016 &, 100 &, 011 &, 160 &, 874 \\
\hline Modal_Kerja_Bersih &, 784 &, 066 &, 889 & 11,864 &, 000 \\
\hline
\end{tabular}

Dependent Variable: Laba

Sumber: Data Diolah Dengan SPSS versi 16.00

Tabel 4-8. Hasil Uji Determinasi

Model Summary ${ }^{b}$

\begin{tabular}{|l|l|l|l|l|l|}
\hline Model & R & R Square & $\begin{array}{l}\text { Adjusted R } \\
\text { Square }\end{array}$ & $\begin{array}{l}\text { Std. Error of } \\
\text { the Estimate }\end{array}$ & Durbin-Watson \\
\hline 1 &, $952^{\mathrm{a}}$ &, 907 &, 898 & 115,0402633 &, 710 \\
\hline
\end{tabular}

Predictors: (Constant), Modal_Kerja_Bersih, Hutang_Jangka_Pendek,

Hutang_Jangka_Panjang

Dependent Variable: Laba

Sumber: Data Diolah Dengan SPSS versi 16.00

Tabel 4-9. Hasil Uji F

ANOVA ${ }^{b}$

\begin{tabular}{|l|l|l|l|l|l|}
\hline Model & Sum of Squares & Df & Mean Square & F & Sig. \\
\hline
\end{tabular}




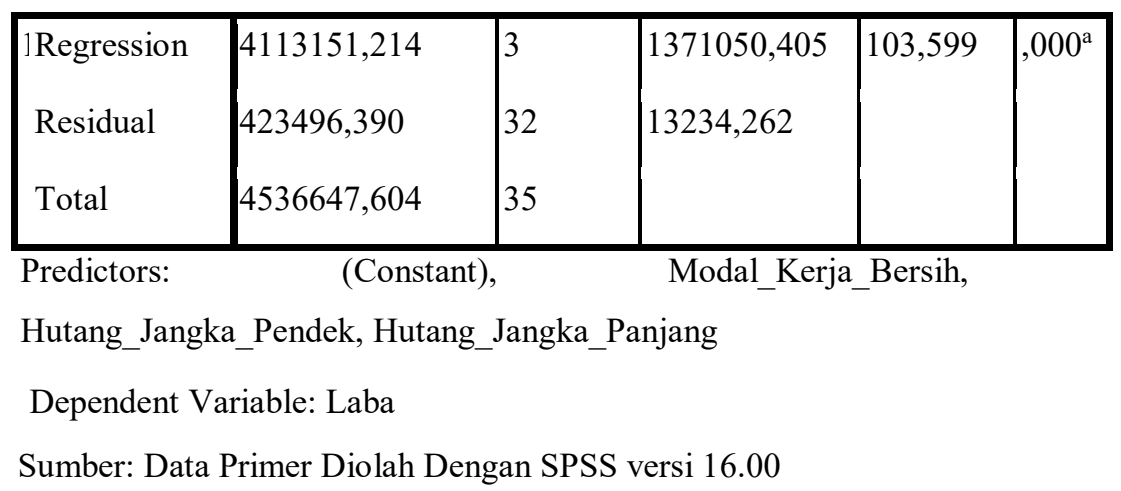

Dari output data table-tabel 4-7, 4-8 dan 4-9 dapat diperoleh hasil sebagai berikut:

- Korelasi antara hutang jangka panjang, hutang jangka pendek dan modal kerja bersih terhadap laba adalah 0,952. Dapat dikatakan bahwa ada hubungan positif yang tinggi sebesar 0,952 antara variabel hutang jangka panjang, hutang jangka pendek dan modal kerja bersih terhadap laba pada PT. Griya Asri Prima.

- Model regresi yang adalah $\mathrm{Y}=-2.348,133+(-0,582) \mathrm{X}_{1}+0,016 \mathrm{X}_{2}+0,784 \mathrm{X}_{3}$

- Model regresi ini memberikan kesimpulan bahwa:

- Konstanta sebesar -2.348,133 dapat dikatakan bahwa tanpa variabel hutang jangka panjang, hutang jangka pendek dan modal kerja bersih, besarnya laba pada PT. Griya Asri Prima tetap terbentuk sebesar -2.348,133

- Variabel hutang Jangka Panjang $\left(\mathrm{X}_{1}\right)$ berpengaruh negatif terhadap laba (Y) dengan nilai koefisien regresi sebesar -0,582. Yang artinya jika variabel hutang jangka panjang menigkat satu satuan maka laba pada PT. Griya Asri Prima akan menurun sebesar 0,582 .

- Variabel hutang Jangka Pendek $\left(\mathrm{X}_{2}\right)$ berpengaruh positif terhadap laba (Y) dengan nilai koefisien regresi sebesar 0,016. Yang artinya jika variabel hutang jangka pendek menigkat satu satuan maka laba pada PT. Griya Asri Prima akan meningkat sebesar 0,016 .

- Variabel modal kerja bersih $\left(\mathrm{X}_{3}\right)$ berpengaruh positif terhadap laba $(\mathrm{Y})$ dengan nilai koefisien sebesar 0,784. Yang artinya jika variabel modal kerja bersih menigkat satu satuan maka laba pada PT. Griya Asri Prima akan meningkat sebesar 0,784.

- Nilai $\mathrm{R}^{2}$ sebesar 0,907. Data tersebut mengidentifikasikan bahwa hutang jangka panjang, hutang jangka pendek dan modal kerja bersih secara bersama-sama memberikan konstribusi sebesar 90,7\% terhadap laba pada PT. Griya Asri Prima, selebihnya 9,3\% dipengaruhi oleh variabel lain yang tidak diteliti. 
- Nilai $F_{\text {hitung }}$ sebesar 103,599 dengan signifikansi $F$ sebesar 0,000, dan nilai $F_{\text {tabel }}=F$ $(0,05 ; 32) 2,90$. Karena nilai $F_{\text {hitung }}>F_{\text {abel }}(103,599>2,90)$ dan signifikasi $F<0,05(0,000$ $<0,05)$, maka $\mathrm{H}_{4} \leq 0$ ditolak $\mathrm{H}_{4} \geq 0$ diterima. Hal ini menunjukkan bahwa hutang jangka panjang, hutang jangka pendek dan modal kerja bersih secara bersama-sama berpengaruh positif dan signifikan terhadap laba pada PT. Griya Asri Prima 


\section{KESIMPULAN DAN SARAN}

\section{Kesimpulan}

Dari uraian yang telah diuraikan pada bab-bab sebelumnya, dapat diperoleh beberapa kesimpulan yaitu sebagai berikut:

1. Variabel hutang jangka panjang $\left(\mathrm{X}_{1}\right)$ berpengaruh negatif terhadap laba $(\mathrm{Y})$ dengan nilai koefisien regresi sebesar -3,635. Yang artinya jika variabel hutang jangka panjang menigkat satu satuan maka laba pada PT. Griya Asri Prima akan menurun sebesar -3,635

2. Variabel hutang Jangka Pendek $\left(\mathrm{X}_{2}\right)$ berpengaruh positif terhadap laba $(\mathrm{Y})$ dengan nilai koefisien regresi sebesar 0,068. Yang artinya jika variabel hutang jangka pendek menigkat satu satuan maka laba pada PT. Griya Asri Prima akan meningkat sebesar 0,068.

3. Variabel modal kerja bersih $\left(\mathrm{X}_{3}\right)$ berpengaruh positif terhadap laba (Y) dengan nilai koefisien sebesar 0,836 . Yang artinya jika variabel modal kerja bersih menigkat satu satuan maka laba pada PT. Griya Asri Prima akan meningkat sebesar 0,836.

4. Hutang jangka panjang, hutang jangka pendek dan modal kerja bersih secara bersamasama berpengaruh positif dan signifikan terhadap laba pada PT. Griya Asri Prima, dengan signifikansi F sebesar 0,000

\section{Saran}

Berdasarkan kesimpulan di atas, penulis memberikan saran-saran sebagai berikut:

1. Dalam melaksanakan pemenuhan kebutuhan dana perusahaan harus selalu mencari alternatif-alternatif sumber dana untuk dianalisa, kemudian dari analisa tersebut diambil keputusan alternative sumber dana mana yang akan dipilih.

2. Modal kerja bersih memberikan kontribusi yang cukup besar terhadap peningkatan laba, oleh karena itu pihak manajemen hendaknya mampu menggunakan modal kerjanya secara efektif dan efisien.

3. Pada penelitian selanjutnya dapat ditambah variabl-variabel lainnya sehingga dapat dilihat variabel mana saja yang memiliki pengaruh dan seberapa besar dapat menyebabkan perubahan terhadap laba. 


\section{DAFTAR PUSTAKA}

Ambarwati, Dwi Sri Asri. 2010. Manajemen Keuangan Lanjut. Ygyakarta: Graha Ilmu.

Arikunto, Suharsimi. 2003. Manajemen Penelitian. Jakrta; Rinerka Cipta.

Armaja, Lukas Setia. 2008. Teori dan Praktik Manajemen Keuangan. Yogyakarta: Liberty.

Brigham dan Houston. 2010. Dasar-Dasar Manajemen Keuangan, Edisi 10. Jakarta: Salemba Empat.

Bungin, Burhan. 2004. Metodologi Penelitian Kuantitatif, Edisi Pertama. Kencana Prehada Media Group.

Djarwanto. 2001. Pokok-pokok Analisis Laporan Keuangan. Yogyakarta: Aditya Media.

Eko, Agus Sujianto. 2007. Aplikasi Statistik dengan SPSS Untuk pemula. Jakarta: Presentasi Pustaka Publisher.

Fred, Jhon Weston. 1988. Manajemen Keuangan, Edisi KeDelapan. Jakarta : Erlangga.

Gill O. James, dan Moira Chatton. Memahami Laporan Keuangan. Jakarta: PPM

Hasan, Iqbal. 2004. Analisis Data Penelitian Dengan Statistik. Jakarta: Bumi Aksara.

James. 2008. Manajemen dan Kebijaksanaan Keuangan Perusahaan. Jakarta : Intermedia.

Jumingan. 2006. Analisis Laporan Keuangan. Jakarta : Bumi Aksara.

Kasmir. 2010. Pengantar Manajemen Keuangan. Jakarta: Kencana.

Kountur, Ronny. 2007. Metodologi Penelititan. Jakarta : PPM.

Moeljadi. Manajemen Keuangan 1, Edisi Pertama. Malang : Bayu Media Publishing.

Munawir. 2007. Analisis Laporan Keuangan, Edisi Ke Empat Cetak Ke Tiga Belas, Yogyakarta : Liberty.

Saragih, Ferdinand D., Adler H. Manurung., dan Jonni Manurung. 2005. Dasar-Dasar Keuangan Bisnis Tteori dan Aplikasi. Cetakan Pertama. Jakarta : PT. ELEX Media Komputindo.

Sjahrial, Darmawan. 2010. Manajemen Keuangan. Jakarta : Mitra Kencana. 
Sugiyono. 2003. Metode Penelitian Administrasi. Bandung: Alfabeta.

Sugiyono. 2009. Metode Penelitian Bisnis. Bandung: Alfabeta.

Sugiyono. 2010. Metode Penelitian Kuantitatif Kualitatif dan R\&D. Bandung: Alfabeta.

Suwartojo. B. Modal Kerja. Jakarta : Balai Aksara.

Van Horne, James C, dan John M. Wachowicz, JR. M. 2005. Prinsip-prinsip Manajemen Keuangan. Jakarta: Salemba Empat.

Van Horne, James C, dan John M. Wachowicz, JR. M. 2007. Prinsip-prinsip Manajemen Keuangan. Jakarta: Salemba Empat.

Van Horne, James C, dan John M. Wachowicz, JR. M. 2010. Prinsip-prinsip Manajemen Keuangan. Jakarta: Salemba Empat.

Wild J. John, Subramanyam, dan Robert F. Halsey. 2005. Financial Statement Analysis. Jakarta: Salemba Empat.

Witjaksono, Armanto. 2006. Akuntansi Biaya 1. Jakarta : Graha Ilmu 